\title{
Pengembangan Strategi Public Relations Menggunakan Pendekatan MARKETING MiX dan SOSTAC TERHAdAP Produk PARIWISATA (STUDI KASUS: PARIWISATA BELITUNG)
}

\author{
${ }^{1}$ Herdi Andrariladchi, ${ }^{2}$ Bugi Satrio Adiwibowo \\ ${ }^{1,2}$ Fakultas Ilmu Komunikasi, Universitas Esa Unggul \\ Email: ${ }^{1}$ herdyladchi@gmail.com, ${ }^{2}$ bugi.satrio@esaunggul.ac.id
}

\begin{abstract}
The purpose of this research to develop the public relations strategy with marketing mix and SOSTAC approach in Belitung tourism. The method of this research was qualitative research with case studies typ in Belitung tourisms. The data sourced from key informant interviewee, field observation, and journal analysis who has related link with this research. All data collected, and analyzed with marketing mix and SOSTAC approach from public relations perspective, then continued to analyzed with SWOT method to mapped the strength, weakness, opportunity and the threat. The results are tourism development in Belitung not involve public relations inside. Low of tourism identification object to fulfil the tourist needs, low of control and evaluation from every process, result in the Belitung tourism was not on the track. Low of price transparency commitment also result in negative perception from the tourist. Next, low of communication between all stakeholders bring about inconsistency of local regulation interpretation regarding tourism concept of Belitung. From that analysis above, the public strategy development offered was develop and maintain the stakeholder relationship (management public relations), do identification and mapping the potential problem will happen and give the solutions to solve the problem (crisis public relations), carry out monitoring and control activity to the tourist to get feedback and carry out communication to all stakeholder (external public relations management), and carry out socialization and publication (public relations campaign).
\end{abstract}

Keywords: Public Relations Strategy, SOSTAC, SWOT, Belitung Tourism.

\begin{abstract}
Abstrak. Tujuan dari penelitian ini untuk mengembangkan strategi hubungan masyarakat dengan bauran pemasaran dan pendekatan SOSTAC di pariwisata Belitung. Metode penelitian ini adalah penelitian kualitatif dengan jenis studi kasus pada pariwisata Belitung. Data bersumber dari informan kunci yang diwawancarai, observasi lapangan, dan analisis jurnal yang memiliki hubungan terkait dengan penelitian ini. Semua data dikumpulkan, dan dianalisis dengan bauran pemasaran dan pendekatan SOSTAC dari perspektif hubungan masyarakat, kemudian dilanjutkan dengan analisis metode SWOT untuk memetakan kekuatan, kelemahan, peluang dan ancaman. Hasilnya adalah pengembangan pariwisata di Belitung tidak melibatkan hubungan masyarakat di dalamnya. Rendahnya objek identifikasi pariwisata untuk memenuhi kebutuhan wisatawan, rendahnya kontrol dan evaluasi dari setiap proses, mengakibatkan pariwisata Belitung tidak berada di jalurnya. Rendahnya komitmen transparansi harga juga menghasilkan persepsi negatif dari wisatawan. Selanjutnya, rendahnya komunikasi antara semua pemangku kepentingan menyebabkan inkonsistensi interpretasi peraturan daerah tentang konsep pariwisata Belitung. Dari analisis di atas, pengembangan strategi publik yang ditawarkan adalah mengembangkan dan menjaga hubungan pemangku kepentingan (manajemen hubungan masyarakat), melakukan identifikasi dan memetakan potensi masalah yang akan terjadi dan memberikan solusi untuk menyelesaikan masalah (krisis hubungan masyarakat), melakukan pemantauan dan mengontrol kegiatan kepada wisatawan untuk mendapatkan umpan balik dan melakukan komunikasi dengan semua pemangku kepentingan (manajemen hubungan masyarakat eksternal), dan melakukan sosialisasi dan publikasi (kampanye hubungan masyarakat).
\end{abstract}

Kata Kunci: Strategi Humas, SOSTAC, SWOT, Pariwisata Belitung 


\section{Pendahuluan}

Perkembangan industri pariwisata tersebut memberikan efek menetes ke bawah (trickling down effect), sehingga perkembangan industri pariwisata untuk beberapa daerah tertentu dirasa kurang memihak kepada lingkungan, masyarakat ataupun sosioekonomi-budaya yang ada di dalam suatu komunitas dimana lokasi industri pariwisata tersebut dikembangkan. Ditambah lagi dengan konsep pengembangan industri pari- wisata yang ada saat ini belum sepenuhnya mengaplikasikan konsep "Sustainable Tourism Ma-nagement" atau pariwisata berkelanjutan. Tentu hal ini semakin menciptakan citra (image) indus- tri pariwisata hanya untuk kelas menengah ke atas.

Melihat kondisi tersebut, untuk menciptakan "konsep pariwisata berkelanjutan" dan merubah citra (image) pariwisata menjadi lebih "merakyat", diperlukan suatu mekanisme atau cara yang mampu memberikan informasi dengan baik dan benar, menggiring opini publik menjadi lebih baik dengan kebenaran informasi yang disajikan, terciptanya hubungan baik antar seluruh pemangku kepentingan yang ada, yang berujung pada meningkatnya jumlah wisatawan yang datang serta meningkatkan perekonomian pariwisata pada masyarakat, maka dibutuhkan figur public relations yang diharapkan mampu menciptakan sebuah strategi untuk pengemba- ngan industri pariwisata.

Pulau Belitung adalah salah satu dari se- kian banyak pulau di Indonesia. Terletak di pantai timur pulau Sumatera atau bersebarangan langsung dengan provinsi Sumatera Selatan me- miliki potensi objek wisata yang sangat besar yang mengantarkan Belitung menjadi The New Bali di Sumatera. Tanjung
Kelayang adalah salah satu aset Belitung yang memiliki potensi luar bisa untuk dikembangkan menjadi industri pariwisata berkelanjutan. Namun potensi ini belum didukung dengan konsep pengembangan yang berkelanjutan, dimana figur public relations menjadi kunci untuk mengantarkan Belitung pada pengembangan destinasi yang berkelanju- tan dan menciptakan suatu prestase atau citra baik.

Tentu, tujuan akhir industri pariwisata dalah untuk mendapatkan keuntungan sebanyak mungkin dengan tingginya angka wisatawan yang datang. Sehingga untuk mendapatkan hal tersebut maka peran public relation terhadap eksternal publik relationnya harus menjadi per- hatian penting. Untuk itu maka, public relation harus mampu mengkombinasikannya dengan pemasaran. Istilah ini lebih dikenal dengan sebutan marketing public relations (MPR). Di- mana marketing public relations bukan hanya sekedar pemasaran, melainkan bagaimana cara membuat pendekatan baik dengan internal atau pun eksternal, memberikan edukasi hingga taha- pan persuasi kepada wisatawan, menjaga hingga mengevaluasi hubungan yang sudah terbina antar seluruh pemangku kepentingan. Karena nominal dan angka bukanlah segalanya, namun hubungan baik yang terbina, prestasi atau citra yang baik mampu membawa peningkatan pendapatan yang siginifikan. Sejalan dengan pernyataan Harris $(1991,12)$ dalam Scriven (2002, 35) juga me- nambahkan bahwa MPR merupakan proses dalam perencanaan, implementasi dan evaluasi program untuk meningkatkan penjualan dan kepuasan pelanggan melalui proses komunikasi efektif dan penyampaian informasi yang kredibel terkait produk yang dibutuhkan, yang diinginkan, dan yang menjadi ketertarikan konsumen. 
Dengan kata lain public relations bukanlah mar- keting, namun public relations mampu mening- katkan jumlah wisatawan yang datang.

Atas dasar latar belakang tersebut, maka penulis tertarik untuk melakukan penelitian pe- ngembangan strategi public relations dalam in- dustri pariwisata dengan mengintegrasikan pen- dekatan marketing public relation dan metode SOSTAC untuk memetakan, mendapatkan dan merumuskan potensi, dan kelemahan yang ada, sehingga dapat dirumuskan suatu strategi public relations dalam pengembangan industri pariwi- sata Belitung.

\section{Metode Penilitian}

Jenis penelitian yang dipergunakan oleh peneliti adalah jenis penelitian Studi Kasus. Jenis peneli- tian ini menjadi rujukan peneliti karena seluruh data yang dipergunakan oleh peneliti bersumber dari data aktual dan informasi-informasi yang ada di lapangan (lokasi penelitian). Peneliti beru- paya sedekat mungkin masuk kedalam organisasi dan berpartisipasi langsung dalam setiap aktifitas yang ada di lokasi penelitian. Hal ini bertujuan untuk mendapatkan informasi yang selengkap-lengkapnya tentang bagaimana aktifitas pengem- bangan pariwisata di Belitung dijalankan. Hal ini sejalan dengan pernyataan Ruslan (2013, 229) metode riset studi kasus banyak menggunakan sumber data yang diteliti, menganalisis dan men- jelaskan secara komprehensif dari berbagai aspek individu, kelompok, program, dan organisasi yang mengalami peristiwa tertentu \& sistematis.

Merujuk pada penjelasan tersebut di atas, Yin $(2012,13)$ menyatakan bahwa penelitian studi kasus, dimana penelitinya diarahkan hanya memiliki peluang yang kecil sekali atau tak mempunyai peluang sama sekali untuk melaku- kan kontrol pada peristiwa yang sudah terjadi pada masa lampau. Hal ini berhubungan dengan bagaimana peneliti mendesain dan menyampai- kan pertanyaan kepada informan. Adapun kali- mat pertanyaan yang dipergunakan adalah "bagaimana" atau "mengapa". Jenis kalimat ta- nya ini untuk memastikan seasli mungkin bahwa suatu peristiwa dapat disajikan dengan apa ada- nya. Adapun menurut Yin $(2012,46)$ ada 4 tipe dasar desain studi kasus, (1) desain kasus tunggal holistic, (2) desain kasus tunggal terjalin, (3) desain multi kasus holistic, (4) desain multi kasus terjalin.

Dalam penelitian ini peneliti menggunakan desain multi kasus terjalin, dengan pertimba- ngan bahwa peneliti melakukan anailisis dilebih dari satu permasalahan dengan sumber data yang didapat dilebih dari satu pemangku kepentingan.

Dalam penelitian ini peneliti mengguna- kan proses analisis kualitatif. Menurut Bogdan dan Biklen di dalam Moleong $(2005,248)$ di dalam Rahayu $(2015,75)$ dinyatakan bahwa ana- lisis data kualitatif adalah analisis yang dilakukan dengan menggunakan data, yaitu mengorgani- sasikan data, memilah data menjadi satuan yang dikelola, mensintesiskannya, mencari dan menemukan pola, menemukan apa yang penting, dan apa yang dipelajari serta memutuskan apa yang dapat diceritakan kepada orang lain.

Selanjutnya ditambahkan pula oleh Sutopo (2006, 105) di dalam Rahayu (2015, 75) karakte- ristik metodologi penelitian kualitatif disebutkan analisisnya bersifat induktif. Dalam hal ini, anali- sis tidak dimaksudkan untuk membuktikan suatu prediksi atau hipotesis penelitian, tetapi semua simpulan yang dibuat sampai dengan teori yang mungkin dikembangkan, dibentuk dari semua data yang berhasil ditemukan dan dikumpulkan dari lokasi penelitian. Sifat 
analisis induktif sangat menekan pentingnya apa yang sebenarnya terjadi dan ditemukan dilokasi penelitian yang pada dasarnya bersifat khusus berdasarkan karakteristik konteks dan kondisi alamiahnya.

Data yang diperoleh, akan dianalisis dengan menggunakan pendekatan marketing mix 6'P yang diintegrasikan dengan metode SOSTAC untuk kemudian hasilnya dianalisis dengan menggunakan metode SWOT. Untuk mendapat- kan strategi pengembangan pariwisata di Beli- tung diperlukan perencanaan yang teliti seorang public relations harus benarbenar paham dengan kondisi aktual yang ada, sehingga perencanaan dan strategi dapat disusun dengan baik. Keku- atan, kelemahan, peluang, dan ancaman (SWOT) harus diidentifikasi dengan jelas dan rinci, sehingga strategi pengembangan yang dihasilkan sudah memperhitungkan potensi dan resiko yang mungkin muncul.

\section{Hasil dan Pembahasan}

Menurut Jeffries $(1971,4)$ di dalam Koutoulas $(2015,6)$ disebutkan bahwa produk pariwisata harus dibedakan dengan destinasi pariwisata, karena destinasi bukan produk pariwisata. Per- nyataan tersebut didukung oleh Framke $(2001,5)$ di dalam Zemla Michal $(2016,3)$ yang menyatakan bahwa produk wisata adalah satu kesatuan yang terdiri dari suatu wilayah geografis yang berisi suatu lansekap, karakteristik budaya, fasi- litas transportasi, makanan dan aktivitas lainnya yang memberikan suatu pengalaman yang luar biasa yang ditawarkan kepada wisatawan.

Menurut Pomering dan Jonson (2009, tanpa halaman) dalam Narwastu (2017, tanpa halaman) menyatakan bahwa produk suatu pari- wisata harus terdiri terdiri dari 3A (atraksi, ak- sesibilitas, dan amenitas), yang merupakan objek intangible ataupun tangible yang dipasarkan kepada konsumen, yang bisa berupa barang atau pun jasa. Kemudian ditambahkan oleh Holloway (1983, tanpa tahun) dalam Cirikovic (2014, 113) bahwa karakterisik definisi dari produk pariwisata adalah; atraksi destinasi; akesbilitas destina- si; dan kondisi tempat tinggal di lokasi destinasi. Dari penjelasan tersebut dapat terlihat bahwa pariwisata tidak bisa berdiri sendiri, amenitas \& aksesbilitas menjadi pendukung pokok untuk hadir melengkapi destinasi yang ada.

\section{Atraksi}

Hingga saat ini atraksi atau destinasi yang ada di Belitung masih memfokuskan diri pada wisata bahari, dibuktikan dengan terpilihnya Tanjung Kelayang sebagai The New Bali. Destinasi unggulan ini menjadi fokus wisatawan untuk datang ke Belitung, Menurut RIPPARKAB (La- poran Akhir 2014), Rencana Strategis Satuan Kerja Perangkat Daerah (RENSTRA-SKPD) Dinas Pariwisata Belitung, serta Perda No. 12

Tahun 2015 telah menyebutkan pengkajian po- tensi kecenderungan produk wisata masa depan, namun laporan kajian terkait hal ini belum tersedia.

Selanjutnya merujuk pada hasil pengama- tan lapangan kecenderungan pasar wisata yang terjadi adalah wisata alam (pantai). Hal ini sesuai dengan penjelasan di dalam Tabel 2.5 dokumen RIPPARKAB (hal 2-69). Namun kendala lainnya yang ada di Belitung adalah tidak adanya kegiatan yang bisa dilakukan oleh wisatawan ketika malam hari, atraksi yang tersedia di Belitung hanya dapat dilakukan pada pagi dan siang hari. Ketika malam hari, wisatawan hanya dapat istirahat di hotel dan 
penginapannya, bah- kan free time ini tidak digunakan maksimal oleh wisatawan untuk melakukan food tour atau pun kegiatan lainnya yang dapat memaksimalkan kegiatan wisatawan dan meningkatkan ekonomi masyarkat.

\section{Aksesibilitas}

Belitung dengan kondisi topografi pulau yang landai sampai dengan sedikit berbukit dan ukuran pulau yang tidak terlalu besar memberikan kemudahan dalam pembangunan sarana transportasi. Adapun kondisi jalan yang terdapat di Belitung disajikan pada Tabel 1 di bawah ini:

Tabel 1. Kondisi Jalan yang Terdapat di Belitung

\begin{tabular}{|c|l|l|l|}
\hline \multirow{2}{*}{ No. } & \multirow{2}{*}{ Kondisi Jalan } & \multicolumn{2}{|l|}{ Panjang Jalan (km) } \\
\cline { 3 - 4 } & & Provinsi & Kabupaten \\
\hline 1 & Baik & 126,01 & 481,95 \\
\hline 2 & Sedang & 6,00 & 88,87 \\
\hline 3 & Rusak & 0 & 57,87 \\
\hline
\end{tabular}

Sumber: Kabupaten Belitung Dalam Angka, tahun 2016 (www.portal.belitungkab.go.id).

Ketersediaan Bandar Udara Internasional H.A.S. Hanandjoeddin di kota Tanjung Pandan menjadi pelengkap ketersediaan sarana aksesi- bilitas Belitung dari luar wilayah Belitung. Dengan panjang landasan pacu 2.250 meter, maka bandara ini telah mampu didarati oleh pesawat dengan tipe ATR, Boeing 800NG, dan Airbus A320, sehingga mampu menambah tingkat aksesibilitas Belitung dari luar wilayah.

Namun masih terdapat kekurangan di bandara Belitung, dimana pada saat sampai ke ruang kedatangan, wisatawan tidak disuguhkan peta atraksi wisata atau peta-peta lokasi wisata yang terdapat di Belitung. Kemudian, untuk alat transportasi angkutan darat dari bandara menuju lokasi objek wisata juga masih sangat kurang, dimana tidak terdapat angkutan publik (seperti bus umum atau yang lainnya) yang tersedia dengan cukup, sehingga wisatawan yang datang sebagian besar menaiki taxi atau telah membuat janji dengan pihak tour operator untuk menyewa kenderaan.

Way, Wuisang dan Supardjo (2016; 29) menyatakan bahwa aksesibilitas adalah sarana yang memberikan kemudahan kepada wisatawan untuk mencapai daerah tujuan wisata. Faktor- faktor penting di dalam aksesibilitas meliputi: denah perjalanan wisata, data atraksi wisata, bandara, transportasi darat, waktu yang dibutuhkan untuk ketempat wisata, biaya untuk transpor- tasi dan banyaknya kenderaan ke tempat wisata. Selanjutnya Sunaryo (2013, 173) di dalam Wilo- po dan Hakim (2017, 59) menyatakan bahwa aksesibilitas pariwisata dimaksudkan sebagai

$$
\begin{aligned}
& \text { "segenap sarana rang } \\
& \text { memberikan kemudahan kepada } \\
& \text { wisatawan untuk mencapai suatu desti- } \\
& \text { nasi maupun tujuan wisata terkait". }
\end{aligned}
$$

\section{Amenitas}

Framke (2001, 5) di dalam Zemla Michal $(2016,3)$ selain lansekap, maka harus tersedia sa- rana prasarana pendukung atau dengan kata lain dikenal dengan istilah amenitas dan aksesibilitas. Menurut Suwantoro (2004, 21-22) di dalam Na- wangsari, Muryani dan Utomowati $(2018,32)$ amenitas adalah tersedianya fasilitas dasar atau pendukung yang berada di objek wisata yang ditujukan untuk memberikan kenyamanan kepa- da wisatawan. Fasilitas yang dimaksud adalah fasilitas yang memberikan kemudahan bagi wisatawan dalam menikmati kegiatan wisata, misal- nya restoran, tempat, ibadah, toko-toko souvenir dan cinderamata, bank, tempat penukaran mata uang, kantor informasi pariwisata, fasilitas kese- hatan dan fasilitas keamanan. 
Kondisi sarana prasarana yang terdapat di Belitung untuk penunjuang kegiatan pariwisata terdiri sebagai berikut:

Tabel 2. Kondisi sarana prasarana yang terdapat di Belitung

\begin{tabular}{|c|l|c|}
\hline No. & \multicolumn{1}{|c|}{$\begin{array}{c}\text { Sarana } \\
\text { Prasarana }\end{array}$} & $\begin{array}{c}\text { Jumlah/Informasi } \\
\text { Ketersediaan }\end{array}$ \\
\hline 1 & Hotel/Penginapan & 56 \\
\hline 2 & $\begin{array}{l}\text { Restoran/Rumah } \\
\text { Makan }\end{array}$ & 120 \\
\hline 3 & Tempat Hiburan & Tidak Tersedia \\
\hline 4 & Rumah Sakit/Klinik & Tersedia \\
\hline 5 & Bank/ATM & Tersedia \\
\hline 6 & Toko Souvenir & Tersedia \\
\hline 7 & Tempat Ibadah & Tersedia \\
\hline 8 & Kantor Informasi & Tidak Tersedia \\
\hline 9 & Fariwisata & Tersedia \\
\hline 10 & $\begin{array}{l}\text { Jasa Transportasi } \\
\text { Publik }\end{array}$ & \\
\hline
\end{tabular}

Sumber: Data dari Dinas Pariwisata

Kabupaten Belitung.

Sugiama (2011) di dalam Wilopo dan Ha- kim (2017, 59) yang menyatakan bahwa ameni- tas meliputi serangkaian fasilitas untuk memenu- hi kebutuhan akomodasi (tempat penginapan), penyediaan makanan dan minuman, tempat hiburan (entertainment), tempat-tempat perbelanjaan, dan layanan lainnya. Kemudian Wilopo dan Hakim $(2017$, 59) juga menambahkan yang dikutip dari Sunaryo (2013, 173) memberikan batasan bahwa amenitas bukan merupakan daya tarik bagi wisatawan, namun dengan kurangnya amenitas akan menjadikan wisatawan menghindari destinasi tersebut. Selanjutnya, Wilopo dan Hakim $(2017,59)$ di dalam Sunaryo (2013, 159) memisahkan fasilitas pendukung yang disebut "Ancillary
Service" yang merupa- kan sarana prasarana umum yang digunakan oleh wisatawan yang mendukung terselenggaranya kegiatan wisata seperti bank, ATM, telekomu- nikasi, rumah sakit dan lain sebagainya.

Peran public relations sangat dibutuhkan untuk membuat, menjaga serta mengevaluasi hubungan dan komunikasi yang ada dan terjalin antar pemangku kepentingan, ini dilakukan untuk dapat memaximalkan kinerja dan hubungan serta komunikasi antar pemangku kepentingan. Salah satu fungsi public relations lainnya adalah untuk dapat memberikan edukasi, informasi, pendeka- tan hingga meningkatkan tingkat kepedulian pemangku kepentingan terkait pengembangan pariwisata yang ada di Belitung.

Tujuan dari produk yang disajikan dengan baik ini adalah untuk dapat mengembangkan dan mendorong perekonomian masyarakat di sekitar Belitung, meningkatkan tingkat kunjungan dan dapat memperkenalkan Belitung hingga kancah internasional, tujuan lainnya adalah ingin mengembangkan destinasi baru secara maksimal. Sesuai dengan RIPPARKAB dan RESNTRA- SKPD yang menyatakan bahwa tujuan dari pengembangan pariwisata Belitung adalah untuk meningkatkan aktivitas dan produktivitas ekono- mi yang berbasis sumber daya alam dan lingku- ngan secara optimal, khususnya di sektor pariwisata, meningkatkan kontribusi sektor ekonomi berbasis sumber daya alam dan lingkungan khususnya sektor pariwisata, serta meningkatkan kesejahteraan masyarakat Belitung.

Berdasarkan penjabaran kondisi aktual produk wisata Belitung tersebut di atas, maka dapat dipetakan kekuatan, peluang, kelemahan dan acaman 
(SWOT) pengembangan produk wisata Belitung sebagai berikut:

Tabel 3. kekuatan, peluang, kelemahan dan acaman (SWOT) pengembangan produk wisata Belitung

\begin{tabular}{|c|c|c|c|}
\hline \multicolumn{2}{|c|}{$\begin{array}{c}\text { Strength-Opportunities } \\
\text { (S-O) }\end{array}$} & \multicolumn{2}{|c|}{$\begin{array}{c}\text { Weakness-Opportunities } \\
\text { (W-O) }\end{array}$} \\
\hline 1. & $\begin{array}{l}\text { Membuat variasi } \\
\text { penyajian produk } \\
\text { wisata dari yang } \\
\text { hanya mengandalkan } \\
\text { wisata alam, ditambah } \\
\text { dengan artificial } \\
\text { tourism (seperti: night } \\
\text { market, wisata kuliner } \\
\text { dengan penyajian } \\
\text { lebih atraktif, wisata } \\
\text { malam, dll. }\end{array}$ & 1. & $\begin{array}{l}\text { Perbaikan teknik } \\
\text { komunikasi dengan } \\
\text { seluruh pemangku } \\
\text { kepentingan dengan } \\
\text { melibatkan public } \\
\text { relations untuk } \\
\text { menyampaikan pesan- } \\
\text { pesan dan program } \\
\text { bersama untuk } \\
\text { mengembangkan } \\
\text { produk wisata } \\
\text { Belitung. }\end{array}$ \\
\hline
\end{tabular}

\begin{tabular}{|c|c|c|c|}
\hline \multicolumn{2}{|r|}{$\begin{array}{l}\text { Opportunities } \\
\text { (Peluang }\end{array}$} & \multicolumn{2}{|r|}{ Threat (Ancaman) } \\
\hline 1 & $\begin{array}{l}\text { Penyajian objek } \\
\text { wisata yang } \\
\text { lebih variatif } \\
\text { dengan } \\
\text { penambahan } \\
\text { aktivitas baru yang } \\
\text { mendukung, seperti } \\
\text { pasar malam (street } \\
\text { food), atraksi }\end{array}$ & 1 & $\begin{array}{l}\text { Kejenuhan } \\
\text { wisatawan dengan } \\
\text { objek wisata yang } \\
\text { monoton tanpa ada } \\
\text { variasi }\end{array}$ \\
\hline 2 & $\begin{array}{l}\text { Pemasaran Desa } \\
\text { Wisata yang lebih } \\
\text { gencar untuk } \\
\text { meningkatkan } \\
\text { kedatangan } \\
\text { wisatawan ke } \\
\text { Desa Wisata }\end{array}$ & 2 & $\begin{array}{l}\text { Wisata yang masif dari } \\
\text { wisatawan tanpa } \\
\text { memperhitungkan } \\
\text { daya dukung } \\
\text { lingkungan/objek } \\
\text { wisata terkait }\end{array}$ \\
\hline 3 & $\begin{array}{l}\text { Kerjasama } \\
\text { antarpemangku } \\
\text { kepentingan } \\
\text { dengan } \\
\text { tujuan sama- } \\
\text { sama untuk } \\
\text { memakismalkan } \\
\text { produk wisata }\end{array}$ & & \\
\hline 4 & $\begin{array}{l}\text { Memasukkan public } \\
\text { relations sebagai } \\
\text { kunci untuk } \\
\text { melakukan } \\
\text { komunikasi } \\
\text { kepada seluruh } \\
\text { pemangku }\end{array}$ & & \\
\hline
\end{tabular}

\section{Setelah dipetakan, maka} dilakukan pengintegrasian untuk mendapatkan sebuah stretegi dalam mengatasi ataupun mengontrol kelemahan dan ancaman yang ada, yaitu sebagai berikut:

Tabel 4. Pengintegrasian Untuk Mendapatkan Sebuah Stretegi dalam Mengatasi ataupun Mengontrol Kelemahan dan Ancaman yang ada

\begin{tabular}{|c|l|c|l|}
\hline \multicolumn{2}{|c|}{ Strength (Kekuatan) } & \multicolumn{2}{|c|}{ Weakness (Kelemahan) } \\
\hline 1. & $\begin{array}{l}\text { Objek wisata alam } \\
\text { yang menarik } \\
\text { (pantai, laut biru, } \\
\text { pasir putih, hutan } \\
\text { alam, dan lain-lain) }\end{array}$ & 1. & $\begin{array}{l}\text { Objek wisata monoton } \\
\text { (hanya menonjolkan } \\
\text { pantai, laut biru, dan } \\
\text { pasir putih), tidak ada } \\
\text { atraksi lain yang } \\
\text { membuat wisatawan } \\
\text { menjadi lebih } \\
\text { penasaran untuk } \\
\text { datang berkunjung }\end{array}$ \\
\hline 2. & $\begin{array}{l}\text { Kemudahan akses } \\
\text { (kondisi jalan baik, } \\
\text { jalan mulus dan } \\
\text { rata) }\end{array}$ & 2. & $\begin{array}{l}\text { Ketersediaan angkutan } \\
\text { publik yang sangat } \\
\text { minim }\end{array}$ \\
\hline 3. & $\begin{array}{l}\text { Akses yang cukup } \\
\text { dekat dari Jakarta }\end{array}$ & 3. & Amenitas yang kurang \\
\hline
\end{tabular}

\begin{tabular}{|c|l|l|l|}
\hline \multicolumn{2}{|c|}{ Strength-Threats (S-T) } & \multicolumn{2}{|c|}{$\begin{array}{l}\text { Weakness - Threat } \\
\text { (W-T) }\end{array}$} \\
\hline 1. & $\begin{array}{l}\text { Variasi penyajian } \\
\text { produk wisata untuk } \\
\text { menghindari } \\
\text { kejenuhan wisatawan, } \\
\text { dengan membuat atau } \\
\text { mendesain jalur } \\
\text { wisata, atau variasi } \\
\text { jenis wisata lain yang } \\
\text { lebih berbeda }\end{array}$ & 1. & $\begin{array}{l}\text { Penyajian variasi } \\
\text { produk wisata }\end{array}$ \\
& 2. & $\begin{array}{l}\text { Pelibatan public } \\
\text { relations untuk } \\
\text { menjaga dan } \\
\text { membina komunikasi } \\
\text { dengan pemangku } \\
\text { kepentingan }\end{array}$ \\
& 3. & $\begin{array}{l}\text { Pengkomunikasian } \\
\text { wisata berkelanjutan } \\
\text { sebagai image/citra } \\
\text { baru produk wisata } \\
\text { Belitung sebagai nilai } \\
\text { jual yang diharapkan } \\
\text { mampu menekan } \\
\text { wisata masif dengan } \\
\text { teknik komunikasi } \\
\text { yang atraktif dan } \\
\text { menarik bagi } \\
\text { wisatawan }\end{array}$ \\
\hline
\end{tabular}

Dalam penyusuan sebuah strategi maka harus memperhatikan tujuan dan sasaran yang akan dicapai. Sebagaimana yang dinyatakan oleh Andrews (1980, Hal: 18) dalam Nickols $(2016,4)$ bahwa konsep strategi adalah suatu pola pengambilan keputusan dalam 
menentukan dan mengungkapkan secara objektif tujuan dan rencana kebijakan bisnis, dimana strategi melibatkan seluruh pemangku kepentingan seperti pekerja, pelanggan (wisatawan) dan komunitas (masyarakat lokal).

Selanjutnya ditambahkan pula oleh Fahey $(1989,28)$ dalam Mainardes, Ferreira and Rapo- so $(2014,47)$ bahwa strategi menjelaskan bagai- mana organisasi menggunakan sumber dan kapa- bilitasnya untuk membangun dan mempertahan- kan keunggulan kompetitif yang menguntungkan dan mempengaruhi keputusan pelanggan dalam memilih untuk melakukan pembelian. Merujuk pada penjelasan tersebut di atas, maka strategi yang dirumuskan adalah sebagai berikut:

1. Variasi penyajian produk wisata, misalnya dengan menambahkan artificial tourism seperti sustainable night market, pasar malam, hiburan malam ataupun aktivitas lainnya yang membuat wisatawan betul- betul memanfaatkan liburan mereka, de- ngan tujuan akhir adalah peningkatan ang- ka wisatawan yang berkunjung serta perputaran nilai uang yang tinggi.

2. Memfokuskan pada pendekatan publik dengan masyarakat di desa wisata, serta membuat perencanaan matang untuk pengembangan desa wisata di Belitung dan berkerjasama dengan tour operators untuk memasarkan desa wisata, menghadirkan influencer pariwisata untuk datang langsung dan membuat video serta vlog terkait desa wisata untuk dibagikan kepada wisa- tawan di seluruh dunia.

3. Perbaikan teknik komunikasi kepada selu- ruh pemangku kepentingan (pelaku wisata, pelaku usaha wisata, organisasi pemerin- tah, organisasi masyarakat dan masya- rakat lokal) dengan melibatkan public re- lations di dalamnya agar hubungan antar pemangku kepentingan dapat dibina dengan baik dan komunikasi dapat terjaga.

Semua pemangku kepentingan yang ada pada industri pariwisata menjadi bagian yang penting dalam pengembangan, semua persiapan hingga evaluasi ini dapat dikerjakan oleh seorang praktisi public relations, dimana seorang praktisi public relations akan dengan mudah melakukan hubungan dan pendekatan dengan seluruh pema- ngku kepentingan untuk kemudian mencari jalan dan strategi juga jawaban unruk permasalahan yang ada serta penanganan permasalahan yang akan dilakukan.

Sejalan dengan pernyataan Petrovici $(2011,18)$ dalam Petrovichi (2014, 68) bahwa public relations merupakan suatu media utama dalam menjaga reputasi dengan tujuan untuk mendapatkan pemahaman dan dukungan juga pengaruh opini dan perilaku publik, ditambahkan oleh Harlow (1976, 36) dalam Palaniappan dan Ramachandraiah (tanpa tahun, 12) menyatakan bahwa public relations adalah suatu fungsi mana- jemen yang membantu dalam membangun dan menjaga hubungan dan timbal balik komunikasi, pemahaman, penerimaan serta kerjasama antara organisasi dengan publik; melibatkan manaje- men permasalahan ataupun masalah; mengatur dalam menjaga informasi dan respon opini pub- lik; mendefinisikan dan menekankan tanggung jawab pada pelayanan untuk kepentingan publik; membantu dan memastikan juga memanfaatkan perubahan secara efektif, berfungsi sebagai sistem peringatan dini untuk membantu meng- antisipasi kejadian 
yang mungkin terjadi; meng- gunakan penelitian dan komunikasi yang baik menjadi alat utama yang dilakukan oleh seorang public relations.

Menurut Palaniappan dan Ramachandra- iah (tanpa tahun, 22-23), strategi untuk menda- patkan tujuan implementasi yang efektif adalah dengan berevolusi. Adapun proses perencanaan antara lain;

a. Menentukan area

b. Menentukan peran

c. Memilih dan mengatur tujuan

d. Mempersiapkan rencana aksi yang berkai- tan dengan pemrograman, penjadwalan, pe- nganggaran, memperbaiki akuntabilitas \& menetapkan aturan dan prosedur.

Sehingga dalam proses bekerjanya, public relations harus menentukan area dan perannya. Dalam hal ini areanya adalah produk wisata Belitung dengan peran seorang public relations yang berfungsi sebagai penjembatan komunikasi dan penyampaian informasi produk, sehingga di- harapkan produk wisata Belitung dapat disam- paikan dengan semenarik dan atraktif mungkin untuk mendorong rasa penasaran dan kaingintahuan wisatawan sehingga mau datang berkun- jung ke Belitung.

Pemelihan teknik komunikasi menjadi sa- ngat penting pada tahapan ini agar informasi yang disampaikan sesuai dengan harapan dan tu- juan strategi, sehingga media komunikasi menja- di salah satu kunci keberhasilan. Sebagaimana yang dinyatakan oleh Rice and Paisley di dalam Palaniappan dan Ramachandraiah menyebutkan bahwa media masa dan komunikasi interpersonal yang saling melengkapi.

Taktik merupakan turunan atau lokus dari sebuah strategi. Taktik adalah sebuah kegiatan yang specifik dan merupakan keluaran (output) dari strategi dan merupakan aspek teknis dari seorang public relations (Botan 2006) dalam Hobbs and Mann (tanpa tahun,
10). Sehingga merujuk pada strategi yang dijelaskan di atas, bentuk taktik yang diperlukan seorang public relations adalah melakukan kampanye, dimana kampanye merupakan suatu kegiatan yang diharapkan dapat mempengaruhi orang banyak dalam waktu yang cukup singkat.

Pada dasarnya kampanye ini meningkat- kan perhatiannya terhadap permasalahan dengan memfasilitasi tujuan efektifitas public relations untuk menghasilkan "stimulasi/rangsangan per- cakapan tentang realitas dan membiarkan persep- si membentuknya". Kampanye ini adalah suatu bentuk pemberian informasi kepada khalayak yang diharapkan bisa membentuk opini publik, menggiring opini dan mempertahankan opini tersebut.

Setelah pemetaan, analisa terhadap kekua- tan, peluang, kelemahan dan ancaman, penyusunan strategi dan taktik dilakukan, maka selanjutnya setelah pengimplementasian adalah melakukan pengontrolan yang harus dilakukan oleh organisasi yang berwenang dalam hal ini adalah Dinas Pariwisata Belitung yang melibatkan pub- lic relations.

Dinas Pariwisata Belitung adalah sebagai Pembina dan perpanjangan tangan dari pemerin- tah, sehingga diharapkan Dinas Pariwisata Beli- tung mampu membina dan mengawal proses ini sesuai dengan tupoksinya. Proses pengontrolan harus dilakukan sedimikian rupa agar dapat termonitoring dan dapat dievaluasi sebagai ben- tuk dan penjabaran dari perbaikan berkelanjutan (continuous improvement) dengan pelibatan seluruh pemangku kepentingan terkait.

\section{Kesimpulan dan Saran}

\section{kesimpulan}

Belitung telah memiliki cukup beragam produk pariwisata yang 
didukung dengan keleng- kapan atraksi wisata dan aksesibilitas yang cukup memadai. Namun atraksi yang ada dirasa belum cukup untuk memenuhi keinginan wisatawan, sebab banyak wisatawan mengeluhkan tidak adanya aktivitas pada malam hari yang dapat dilakukan. Dalam perkembangannya, Dinas Pari- wisata Belitung dan Pelaku Usaha Pariwisata di Belitung belum melibatkan Public Relations dalam upaya membangun sinergi dan penyamaan tujuan antar seluruh pemangku kepentingan terkait dalam pengembangan pariwisata Belitung, sehingga komunikasi antar pemangku ke- pentingan tidak berjalan dengan baik.

Selanjutnya, keterbatasan sumberdaya ma- nusia pariwisata yang mengerti tentang industri pariwisata juga menjadi kendala dalam pengem- bangan produk wisata Belitung. Serta yang terakhir adalah manajemen lokasi atraksi wisata yang belum maksimal, dimana banyak sekali dijumpai sampah dilokasi atraksi wisata yang tidak terke- lola dengan sangat baik.

\section{Saran}

1. Dinas Pariwisata Belitung idealnya harus melakukan jajak pendapat atau survey ke- puasan wisatawan yang datang ke Belitung, untuk mengetahui sejauh apa tingkat kepuasan wisatawan yang datang ke Beli- tung, apakah mereka merasa cukup dengan atraksi wisata yang ada, ataukah mereka ingin mendapatkan atraksi wisata lainnya di Belitung, mengingat berdasarkan hasil wawancara para wisatawan merasa bi- ngung ketika malam hari tiba, karena tidaklada ada aktivitas wisata yang bisa mereka lakukan.

2. Penggunaan media website berupa media sosial dan media interaktif lainnya seha- rusnya diaktifkan dan dimaksimalnya me- ngingat hampir seluruh wisatawan yang datang menyatakan mereka mendapatkan informasi Belitung bersumber dari media sosial rekan mereka. Hal ini karena sumber informasi yang paling banyak dilihat ada- lah media sosial. Selain itu penggunaan media sosial juga lebih murah dibandingan dengan wadah promosi lainnya, dan dirasa lebih efektif dibanding dengan media lain- nya karena menjangkau semua level ma- syarakat.

3. Penggunaan Youtube dan endorser sepertiBest Ever Food Review Show atau MarkWiens sebagai media dalam penyebaran informasi pariwisata Belitung. Ini dilaku- kan untuk mencapai wisatawan dari berba- gai belahan dunia. Dengan penyebaran informasi secara luas dan mendunia ini diharapkan pariwisata Belitung dapat berkembang secara baik dan meningkat dari tahun ke tahunnya. Banyaknya pengguna youtube dan media sosial menjadikan peluang yang besar yang bisa digunakan untuk memasarkan destinasi pariwisata di Belitung.

\section{Daftar Pustaka}

Cirikovic Elida. (2014). Marketing Mix in

Tourism.http://www.dukagjinicolleg e.eu/r esearch/Elida\%20Cirikovic(fq 135141).pdf. Diunduh pada 16 April 2018.

Hobss Micthell dan Mann Alana. (Tanpa Tahun).Public Relations: Strategy 
and

Tactics.http://lib.oup.com.au/he/med ia journalis

m/Chalkley CDMEL2e Online.pdf.

Diunduh pada 17 Desember 2017.

Koutoulas

Dimitris.

(2004).

Understanding the Tourist Product. Interim symposium of the Research Committee on International Tourism (RC 50) of the International Sociological Association (ISA). https://

www.researchgate.net/publication/2 80317594_Understanding_the_Tour ism_Product. Diunduh pada 20 November 2018.

Khotimah Khusnul, Wilopo, dan Hakim Luckman. (2017). Strategi Pengembangan Destinasi Pariwisata Budaya (Studi Kasus pada Situs Trowulan sebagai Pariwisata Budaya Unggulan di Kabupaten Mojokerto).https://media.neliti.com/medi a/publ ications/87665-IDstrategipengembangan- destinasipariwisa.pdf. Diunduh pada 11 November 2018.

Mainardes, Ferreira and Raposo. (2014). Startegy and Strategic Management Concepts: Are They Recognised By Management Students. Journal of Business Administra- tion and Management, Vol. 1, XVII. http://www.fucape.br/_public/produ cao_c

ientifica/2/Strategy\%20And\%20Stra tegic. pdf. Diunduh pada 19 April 2018.

Nawangsari Dyanita, Muryani Chatarina, Utomowati Rahning. (2018). Pengem- bangan Wisata Pantai Desa Watu Karung dan Desa Sedang Kabupaten PACTAN Tahun $2017 . \quad$ https://jurnal.uns.ac.id/ GeoEco/article/d ownload/19172/15196. Diunduh pada 11 November 2018.

Narwastu Florentiana Woro. (2017). Marketing Mix In Tourism. https://www.linkedin.com/pulse/mar keting-mix-tourism-florentina-woro. Diakses pada 19 Agustus 2018.

Nickols Fred., Strategy Definitions \& Meanings. (2016). Hand Book. http://www.nickols.us/strategy defi

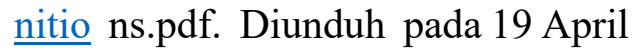
2018.

Petrovici Amalia. (2014). Public Relations in Tourism. A Research on The Perception of The Romanian Public Upon Responsible Tourism. Procedia - Social and Behavioral Sciences 163 